\title{
Pemberdayaan Masyarakat Melalui Pengelolaan Sampah Skala Rumah Tangga Menggunakan Metode Komposting
}

\author{
${ }^{1}$ Ika Nurani Dewi, ${ }^{2}$ Ida Royani, ${ }^{\mathbf{3}}$ Sumarjan, ${ }^{4}$ Husnul Jannah \\ ${ }^{1,2}$ Universitas Pendidikan Mandalika, Jl. Pemuda No. 59A, Mataram, Indonesia 83125 \\ ${ }^{3}$ Universitas Mataram. Jl. Majapahit No 62 Mataram
}

Email Korespondensi: ikanuranidewi@ikipmataram.ac.id

\begin{tabular}{|c|c|}
\hline Article Info & bstract \\
\hline $\begin{array}{l}\text { Article History } \\
\text { Received: } 05-02-2020 \\
\text { Revised: } 14-02-2020 \\
\text { Published: } 28-02-2020\end{array}$ & \multirow[b]{2}{*}{$\begin{array}{l}\text { Community Empowerment Through Household Scale Waste Management } \\
\text { Using Composting Methods. Along with the increasing population in an area, } \\
\text { will result in an increase in the volume of waste. Community consumption } \\
\text { patterns also contribute to increasing the volume of waste that is increasingly } \\
\text { diverse. So far, the waste management carried out by the community in RT } 04 \\
\text { Pejeruk Bangket is still limited to the system of garbage collection, garbage } \\
\text { transportation, and disposal to TPSA, while the capacity of TPSA is } \\
\text { increasingly limited. The solution to overcome these problems is to empower } \\
\text { the community in household scale waste management by composting. The } \\
\text { purpose of this community service activity is to improve the knowledge and } \\
\text { skills of housewives and young people in RT 04 Pejeruk Bangket about waste } \\
\text { management using the composting method. The method of implementing } \\
\text { activities uses the lecture, discussion and demonstration methods. } \\
\text { Implementation of activities carried out from December } 2019-\text { February } 2020 . \\
\text { The implementation of community service activities as a whole was carried out } \\
\text { well. This can be seen from the number of trainees at } 85.07 \% \text {, the knowledge } \\
\text { and skills of participants in mastering the material by 73.13\%, and the } \\
\text { response of trainees } 91.88 \% \text {. Supporting factors for household scale waste } \\
\text { management activities are support from the Head of the Environment, Head of } \\
\text { RT O4 and the enthusiasm of community service participants, while the } \\
\text { inhibiting factor for activities is the synergy between the community and the } \\
\text { local government is not optimal }\end{array}$} \\
\hline $\begin{array}{l}\text { Keywords } \\
\text { processing, } \\
\text { community, } \\
\text { organic waste, } \\
\text { composting }\end{array}$ & \\
\hline Info & Abstrak \\
\hline $\begin{array}{l}\text { Sejarah Artikel } \\
\text { Diterima: 05-02-2020 } \\
\text { Direvisi: } 14-02-2020 \\
\text { Dipublikasi: } 28-02-2020\end{array}$ & \multirow{2}{*}{$\begin{array}{l}\text { Seiring dengan meningkatnya jumlah penduduk di suatu wilayah, akan } \\
\text { mengakibatkan bertambahnya volume sampah. Pola konsumsi masyarakat ikut } \\
\text { memberi kontribusi dalam peningkatan volume sampah yang semakin beragam. } \\
\text { Sejauh ini penggelolaan sampah yang dilakukan oleh masyarakat di lingkungan } \\
\text { RT } 04 \text { Pejeruk Bangket masih terbatas pada sistem pengumpulan sampah, } \\
\text { pengangkutan sampah, dan pembuangan ke TPSA, sedangkan daya tampung } \\
\text { TPSA semakin terbatas. Solusi untuk mengatasi permasalahan tersebut adalah } \\
\text { dengan memberdayakan masyarakat dalam pengolahan sampah skala rumah } \\
\text { tangga dengan metode komposting. Tujuan kegiatan pengabdian ini adalah } \\
\text { meningkatkan pengetahuan dan keterampilan ibu rumah tangga dan pemuda di } \\
\text { lingkungan RT 04 Pejeruk Bangket tentang pengeloaan sampah menggunakan } \\
\text { metode komposting. Metode pelaksanaan kegiatan menggunakan metode } \\
\text { ceramah, diskusi dan demonstrasi. Pelaksanaan kegiatan dilaksanakan mulai } \\
\text { bulan Desember } 2019 \text { - Februari } 2020 \text {. Pelaksanaan kegiatan pengabdian } \\
\text { secara keseluruhan terlaksana dengan baik. Hal ini terlihat dari jumlah peserta } \\
\text { pelatihan sebesar } 85.07 \% \text {, pengetahuan dan keterampilan peserta dalam } \\
\text { menguasai materi sebesar } 73.13 \% \text {, dan respon peserta pelatihan } 91.88 \% \text {. Faktor } \\
\text { pendukung kegiatan pengolahan sampah skala rumah tangga adanya dukungan } \\
\text { dari Kepala Lingkungan, Ketua RT 04 dan antusiasme peserta pengabdian, }\end{array}$} \\
\hline & \\
\hline
\end{tabular}


sedangkan faktor penghambat kegiatan adalah sinergi antara masyarakat dengan pemerintah lokal belum optimal.

Sitasi: Dewi N K., Royani I., Sumarjan, Jannah H., (2020) Pemberdayaan Masyarakat Melalui Pengelolaan Sampah Skala Rumah Tangga Menggunakan Metode Komposting. Sasambo: Jurnal Abdimas (Journal of Community Service). 2(1), 12-18. Doi: 10.36312/sasambo.v2i1.172

\section{PENDAHULUAN}

Seiring dengan meningkatnya jumlah penduduk di suatu wilayah, akan mengakibatkan bertambahnya volume sampah. Pola konsumsi barang primer, sekunder, maupun tersier oleh rumah tangga maupun publik memberikan kontribusi dalam peningkatan volume sampah yang semakin beragam. Sampah merupakan salah satu permasalahan lingkungan yang memerlukan penanganan serius. Sampah adalah suatu benda yang tidak digunakan atau tidak dikehendaki dan harus dibuang, yang dihasilkan oleh kegiatan manusia (Wahyono, 2011). Sampah dapat berupa bahan padatan, cair dan gas yang bisa bersumber dari rumah tangga, pasar, warung, kantor, dan pabrik. Sampah yang berasal dari pemukiman merupakan salah satu sumber sampah yang cukup besar perannya dalam peningkatan volume sampah di lingkungan. Sampah yang berasal dari pemukiman atau disebut dengan sampah rumah tangga sebanyak $75 \%$ terdiri dari sampah organik dan sisanya anorganik (Sulistiyani \& Wulandari, 2017). Seiring dengan laju kegiatan rumah tangga, harus diikuti dengan teknik pengelolaan sampah yang baik. Akan tetapi, kapasitas penanganan sampah yang selama ini dilakukan oleh masyarakat maupun pemerintah daerah belum optimal. Hal ini terlihat dari penumpukan sampah yang sering kali terlihat di beberapa pasar tradisional dan aktivitas pembakaran sampah yang masih sering dilakukan oleh masyarakat. Pengelolaan sampah yang kurang baik dapat memberikan dampak negatif pada lingkungan, seperti timbulnya penyakit, sanitasi lingkungan menjadi buruk, turunnya kandungan organik lahan, dan mempercepat terjadinya pemanasan global (Ilhamdi dkk, 2019).

Beberapa permasalahan terkait dengan sampah yang teridentifikasi di wilayah RT 04 Desa Pejeruk Bangket diantaranya yaitu: peningkatan volume sampah seiring dengan bertambahnya jumlah penduduk, kebiasaan masyarakat membuang sampah tanpa pemilahan, dan peran masyarakat dalam pengelolaan sampah yang sebagian besar masih sebatas pada sistem pengumpulan sampah, pengangkutan sampah, dan pembuangan ke Tempat Pembuangan Sampah Akhir (TPSA), sedangkan daya tampung TPSA semakin terbatas. Selain itu, sampah yang dibuang oleh masyarakat tanpa melalui proses pemilahan akan menimbulkan bau yang tidak sedap dan menjadi sarang bagi berbagai jenis hewan. Rangkuti (2014) menjelaskan bahwa dampak negatif keberadaan TPSA adalah mengganggu kenyamanan masyarakat serta terjadi penurunan tingkat kesehatan dan kualitas lingkungan sekitar.

Komitmen bersama antar masyarakat dan perangkat desa dalam pengolahan sampah sangat diperlukan, sehingga tidak menimbulkan berbagai permasalahan lingkungan. Peran masyarakat dalam pengelolaan sampah tidak hanya sebatas dalam membuang sampah di tempat yang seharusnya, namun diharapkan termasuk juga mampu mengolah sampah yang memberikan manfaat kembali bagi masyarakat. Oleh sebab itu, diperlukan peran perguruan tinggi dalam rangka melakukan transfer ilmu pengetahuan tentang pengolahan sampah yang benar dan efektif yang dapat diterapkan oleh masyarakat. Mereduksi timbunan sampah dengan melakukan 3R (Reduce, Reuse dan Recyle) dilanjutkan dengan kegiatan komposting sampah organik rumah tangga menjadi kompos dinilai efektif (Faizah, 2008).

Metode komposting adalah teknik menghasilkan kompos dari bahan organik melalui proses dekomposisi dengan bantuan mikroorganisme pengurai (Ermavitalini dkk, 2019). Kompos mengandung hara mineral yang esensial untuk menyuburkan lahan dan tanaman produktif maupun tanaman penghijauan yang bersifat ramah lingkungan (Widarti dkk, 2015). Keunggulan metode komposting teknologinya sederhana, proses pembuatannya mudah dan 
bahan yang dibutuhkan tersedia di sekitar kita. Dengan demikian, kegiatan pengolahan sampah menggunakan teknik komposting dapat menjadi solusi untuk mengatasi masalah sampah. Kegiatan pengolahan sampah skala rumah tangga menjadi kompos memiliki tujuan: (1) meningkatkan pengetahuan dan keterampilan masyarakat tentang pengolahan sampah rumah tangga, (2) memberdayakan masyarakat dalam pengolahan sampah rumah tangga, (3) menambah pendapatan masyarakat. Adapun manfaat dari program tersebut memiliki tiga manfaat, yaitu: 1) nilai pengetahuan, mengkonversi (reuse \& recycle) sampah menjadi kompos, 2) nilai konservasi, yakni untuk mengurangi (reduce) volume sampah yang dibuang ke TPAS, dan 3) nilai ekonomi, yakni mendatangkan keuntungan ekonomi dari hasil penjualan kompos.

\section{METODE}

Kegiatan ini dilaksanakan di Desa Pejeruk Bangket Ampenan. Pelaksanaan kegiatan dilakukan mulai bulan Januari-Februari 2020 yang meliputi kegiatan persiapan hingga tahapan pelaporan. Untuk melaksanakan kegiatan pengolahan sampah rumah tangga menjadi kompos dilakukan secara bermitra antara tim budi daya tanaman Universitas Pendidikan Mandalika dan Universitas Mataram. Agar pelaksanaan program pengabdian ini lebih terarah, maka metode yang digunakan adalah metode difusi ilmu pengetahuan dan teknologi. Metode difusi ilmu pengetahuan dan teknologi duterapkan melalui ceramah, diskusi, tanya jawab, praktik dan pendampingan (Hunaepi, dkk, 2019). Bentuk pelaksanaan kegiatan pengolahan sampah rumah tangga menjadi kompos diuraikan sebagai berikut:

1. Tahap sosialisasi dan penyuluhan

Pada hari pertama dilaksanakan kegiatan sosialisasi diisi dengan pembekalan wawasan teoritik dan aplikatif tentang pengolahan sampah skala rumah tangga menggunakan teknik komposting. Kegiatan sosialisasi ini melibatkan tim dari UNDIKMA dan UNRAM dengan metode ceramah dan diskusi kelompok. Materi sosialisasi meliputi peran pemuda dan ibu rumah tangga dalam pengelolaan lingkungan hidup, klasifikasi sampah, dan teknik mengolah sampah organik menggunakan metode komposting. Selanjutnya dilakukan kegiatan diskusi atau tanya jawab mengenai hal yang berkaitan dengan sampah dan pengolahannya.

2. Tahap pelaksanaan pengolahan sampah

Kegiatan selanjutnya adalah pelatihan pemilahan sampah dan komposting sampah dengan menggunakan bahan baku dan alat sederhana. Peserta mempraktekkan secara langsung proses pembuatan kompos yang dipandu oleh pakar. Pada saat kegiatan pelatihan, peserta diminta untuk membawa bahan berupa sampah atau limbah dapur rumah tangga masing-masing, seperti sisa sayuran hijau, dan kulit buah-buahan. Penggandaan alat komposting dan bahan aktivator EM4 disediakan oleh tim penyuluh. Metode yang dilakukan yaitu melakukan fermentasi aerob dengan menggunakan campuran EM4 dengan waktu fermentasi 14-30 hari (Suhastyo, 2017). Pelatihan pembuatan kompos dilakukan melalui tahapan: 1) sampah organik dipotong-potong menjadi ukuran yang lebih kecil, 2) sampah dimasukkan dalam bak komposter dan dicampurkan dengan larutan EM4, 3) setelah satu bulan kompos telah siap untuk digunakan.

3. Tahap refleksi pelatihan

Setelah mempraktikkan pengolahan sampah organik menjadi kompos dibimbing oleh pakar melalui kegiatan pendampingan. Hal-hal yang menjadi perhatian adalah kekurangan dan kelebihan pelaksanaan kegiatan pengolahan sampah rumah tangga menjadi kompos. Kegiatan yang dilakukan pada tahap refleksi yaitu: 1) refleksi hasil pelatihan, 2) pendampingan dalam tidak lanjut pengembangan program. Tahap selanjutnya diharapkan masyarakat lingkungan Pejeruk Bangket secara keseluruhan akan melaksanakan program tersebut secara partisipatif atau mandiri dengan membagi ilmu ke anggota masyarakat yang lain. 


\section{HASIL DAN PEMBAHASAN}

Hasil survei dan diskusi dengan perangkat Desa Pejeruk Bangket, kondisi lingkungan menunjukkan volume sampah yang semakin menumpuk setiap hari dan bercampur aduk antara sampah organik dan anorganik. Berdasarkan hasil tersebut, diperlukan program pengabdian kepada masyarakat berupa pelatihan pengolahan sampah skala rumah tangga. Perangkat desa memberikan tanggapan dan respon positif, program yang ditawarkan sesuai dengan kebutuhan mengingat masalah sampah merupakan masalah yang sampai saat ini belum ada solusi atau penanganan yang tepat. Dengan adanya kegiatan pelatihan pengolahan sampah, diharapkan dapat mengubah perilaku masyarakat dalam mengelola sampah. Masyarakat juga mampu membuat kompos dari limbah organik dapur rumah tangga. Kompos tersebut dapat digunakan sebagai pupuk tanaman, sehingga lingkungan menjadi bersih dan nyaman. Selain itu, program pengabdian dapat menjalin silaturahmi antara civitas akademik perguruan tinggi dengan masyarakat desa.

Sasaran masyarakat dalam program pengabdian berjumlah 67 orang yang terdiri dari ibu rumah tangga dan pemuda RT O4 Pejeruk Bangket. Wilayah RT 04 dipilih sebagai subyek pengabdian karena organisasi kemasyarakatan Pemberdayaan Kesejateraan Keluarga (PKK) dan Karang Taruna di RT 04 lebih berkembang dibandingkan dengan wilayah RT lain yang berada di Lingkungan Pejeruk Bangket. Penilaian kinerja masyarakat dalam kegiatan pengabdian dapat dilihat pada Tabel 1 di bawah ini:

Tabel 1. Penilaian Kinerja Masyarakat Desa Pejeruk Bangket

\begin{tabular}{llc}
\hline No & Indikator yang diamati & Persentase \\
\hline 1. & Kehadiran masyarakat berdasarkan undangan & 85.07 \\
2. & Keterampilan mengolah sampah organik dengan metode komposting & 73.13 \\
3. & Respon peserta pelatihan & 91.88 \\
\hline
\end{tabular}

Kegiatan sosialisasi dan penyuluhan tentang pengelolaan sampah skala rumah tangga dilaksanakan pada hari Rabu, 8 Januari 2020 pukul 16.30 WITA bertempat di rumah Ibu Sri Wijayanti warga RT 04. Berdasarkan hasil evaluasi tingkat partisipasi peserta pelatihan pada kegiatan penyuluhan dalam kategori baik. Hal ini terlihat dari jumlah peserta pelatihan yang hadir dalam kegiatan penyuluhan sebanyak 57 orang dari total 67 orang atau sebesar $85.07 \%$. Hasil tersebut menunjukkan bahwa program pelatihan pengolahan sampah skala rumah tangga dapat memunculkan aspek pemberdayaan masyarakat dan meningkatkan motivasi masyarakat. Pada diskusi banyak peserta yang antusias menanyakan tentang teknik pemilahan sampah berdasarkan jenisnya, jenis sampah apa saja yang dapat digunakan sebagai bahan pembuatan kompos, dan cara mengolah sampah menggunakan teknik komposting.

Pada tahap pelaksanaan peserta mempraktekkan secara langsung proses pengomposan menggunakan bahan yang telah dibawa dari rumah masing-masing. Sampah organik dipotong dengan kecil, selanjutnya dimasukkan dalam bak pengomposan bersama bahan aktivator EM4 dan didiamkan selama \pm 30 hari. Penambahan aktivator EM4 berperan untuk mempercepat proses pengomposan limbah organik (Rahmawati \& Dony, 2014). Dalam komposting sampah rumah tangga seperti cangkang telur dan tulang tidak perlu digunakan karena dapat memperlambat proses pengomposan dan menimbulkan bau yang busuk. Setelah proses pencampuran bahan selesai, selanjutnya adalah proses fermentasi/pengomposan dalam bak yang telah ditutup rapat, sehingga pengomposan yang terjadi secara anaerob. Kelembaban yang dibutuhkan adalah sekitar 50-60\% agar mikroba tetap beraktivitas (Simanungkalit, 2009). Dalam waktu 1 bulan (30 hari) sampah organik yang telah mengalami proses fermentasi telah berubah menjadi kompos yang berwarna hitam dan berbau tanah. Kompos sangat berperan dalam peningkatan produksi tanaman, mengurangi pencemaran lingkungan, dan meningkatkan kualitas lahan secara berkelanjutan (Matenggomena, 2013). Kegiatan penyuluhan dan pelatihan pengolahan sampah skala rumah tangga menggunakan metode komposting ditunjukkan Gambar1. 


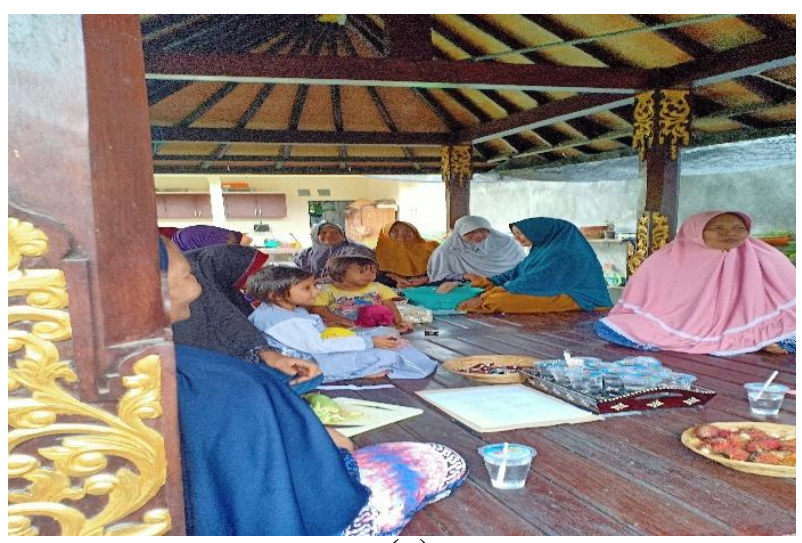

(a)

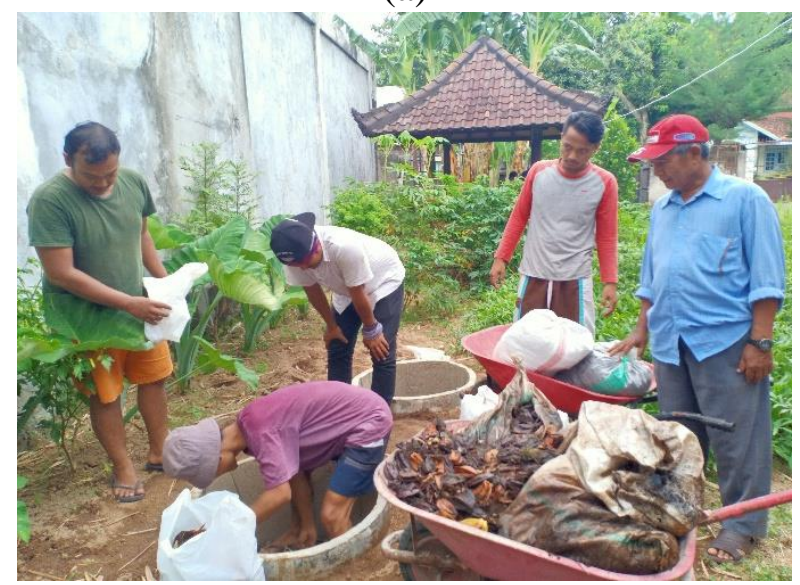

(c)

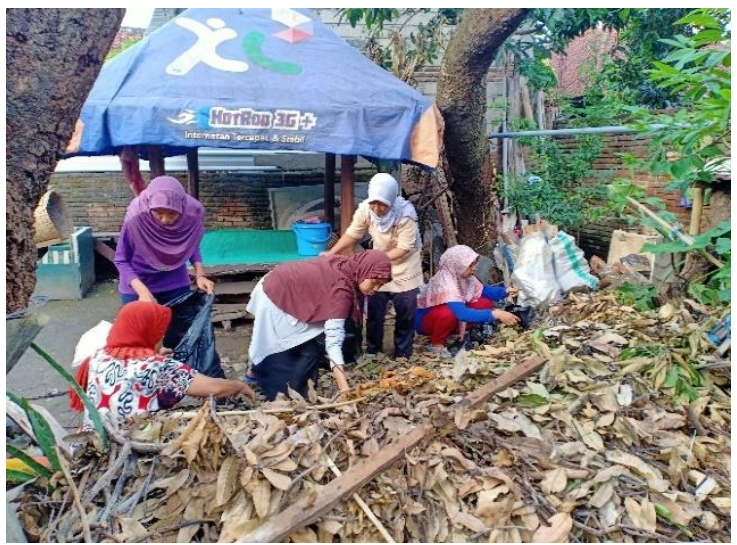

(b)

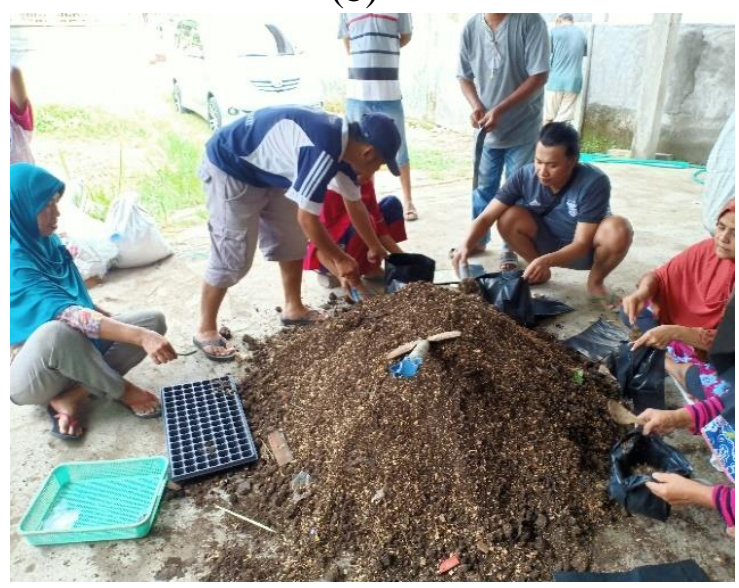

(d)

Keterangan :

(a) Sosialisasi dan penyuluhan pengelolaan sampah skafa rumah tangga

(b) Proses pemilahan sampah

(c) Pelatihan pengolahan sampah organik menggunakan metode komposting

(d) Kompos yang telah jadi

Umpan balik dilakukan untuk mengukur tingkat keterampilan peserta dalam memilah sampah, membuat kompos, dan kerja sama dengan sesama peserta pelatihan. Berdasarkan hasil umpan balik diperoleh bahwa keterampilan memilah sampah mengacu pada keterampilan memilah sampah ke dalam kategori sampah plastik, sampah kertas dan sampah umum. Tingkat keterampilan pengomposan mengacu pada keterampilan masing-masing peserta pelatihan membuat kompos dengan menggunakan teknik komposting. Berdasarkan hasil evaluasi pengetahuan dan keterampilan diperoleh hasil $73.13 \%$ peserta pelatihan menguasai materi atau dalam kategori baik. Kemampuan para peserta yang berbeda dalam menyerap materi yang disampaikan menyebabkan pengetahuan dan keterampilan belum tercapai maksimal.

Pada akhir pelaksanaan pelatihan, peserta diminta untuk mengisi kuesioner untuk mengetahui respon peserta terhadap program pengabdian yang dilaksanakan. Berdasarkan hasil analisis kuesioner diperoleh hasil bahwa masyarakat memberikan respon positif terhadap kegiatan yang dilaksanakan, karena memperoleh pengetahuan baru. Masyarakat berpendapat bahwa transfer teknologi pengolahan sampah rumah tangga menggunakan metode komposting memberikan manfaat yang besar, yaitu adanya peningkatan pengetahuan, sehingga ke depannya masyarakat lingkungan Pejeruk Bangket mampu membuat sendiri kompos dari sampah rumah tangga. Hal ini juga mampu melatih kemandirian masyarakat memanfaatkan potensi yang ada di sekitar sebaga bahan baku pupuk organik untuk mewujudkan ketahanan pangan. 


\section{KESIMPULAN}

Berdasarkan dari kegiatan yang telah dilakukan dapat disimpulkan bahwa secara keseluruhan kegiatan pelatihan pengolahan sampah menggunakan metode komposting dalam kategori baik. Hal ini terlihat dari jumlah peserta pelatihan sebesar $85.07 \%$, pengetahuan dan keterampilan peserta dalam menguasai materi sebesar $73.13 \%$, dan respon peserta pelatihan $91.88 \%$.

\section{SARAN}

Saran dalam kegiatan pengolahan sampah skala rumah tangga perlu terus diupayakan mengingat volume sampah yang terus meningkat. Perangkat Desa Pejeruk Bangket dan Perguruan Tinggi juga perlu mengupayakan langkah strategis dari untuk melanjutkan kegiatan pengolahan sampah rumah tangga agar cakupannya lebih luas, sehingga harapan untuk menjadikan Desa Pejeruk sebagai pionir pengolah sampah skala rumah tangga terwujud.

\section{UCAPAN TERIMA KASIH}

Kegiatan ini didukung oleh program studi pendidikan biologi Fakultas Sains, Teknik, dan Terapan Universitas Pendidikan Mandalika, dan Fakultas Pertanian Universitas Mataram. Selain itu kegiatan ini didukung penuh oleh mitra.

\section{DAFTAR PUSTAKA}

Ermavitalini.D., Jadid, N.,Muslihatin, W., Saputro, B. T., Shovitn, M., Prasetyo, N. E., Saa'dah, N. N., \& Purwani, I. K. (2019). Pelatihan Komposting Sampah Skala Rumah Tangga dalam Pengolahan Sampah Berbasis Masyarakat Desa Ketegan Tanggulangin Sidoarjo. Jurnal ABDI, 5(1). 39-43. journal.unesa.ac.id

Faizah, (2008). Pengolahan Sampah Rumah Tangga Berbasis Masyarakat (Studi Kasus di Kota Yogyakarta). Tesis Magister Ilmu Lingkungan. Universitas Diponegoro. Semarang. eprints.undip.ac.id

Hunaepi, Asy'ari, M, Samsuri, T., Mirawati, B., Firdaus, L., Fitriani, H., Muhali, Prayogi, S. (2019). Budidaya Jamur Tiram di Pondok Pesantren Hidayaturrahman NW Manggala. Sasambo: Jurnal Abdimas (Journal of Community Service), 1(1), 45-52. doi: 10.36312/sasambo.v1i1.119

Ilhamdi, L.W., Handayani, Y., Saputri, A., Anjani, M., Najjah, S, S., Yulianingsih, E., Rahmatullah, M, T., Marzia, E., Yogasworo, A., Mustakim \& Wira, I, D, P. (2019). Penyuluhan, pelatihan dan pendampingan pengelolaan limbah rumah tangga menjadi pupuk organik di Desa Kerumut Kecamatan Pringgabaya. Jurnal Pengabdian Magister Pendidikan IPA, 1(2), 108-116. jppipa.unram.ac.id

Matenggomena, M.F (2013). Pemanfaatan sampah rumah tangga untuk budi daya tanaman sayuran organik di pekarangan rumah. Agroinovasi, XLIII(3503), 17-23.

Rahmawanti, N., \& Dony, N (2014). Pembuatan pupuk organik berbahan sampah organik rumah tangga dengan penambahan aktivator EM4 di daerah Kayu Tangi. Jurnal Ziraah'ah, 39(1), 1-7. ojs.uniska-bjm.ac.id

Rangkuti, F. A (2014). Dampak Keberadaan Tempat Pembuangan Akhir Sampah "Namo Bintang" Terhadap Masyarakat (Studi kasus: Desa Namo Bintang, Kecamatan Pancur Batu, Kabupaten Deli Serdang). Skripsi. IPB. Bogor.

Simanungkalit, R.D.M., Suriadikarta, D.A., Saraswati R., Setyorini D., \& Hartatik W (2009). Teknik Pembuatan Kompos. Informasi Ringkas Bank Pengetahuan Padi Indonesia.

Sulistiyani, T. A \& Wulandari, Y. (2017). Proses pemberdayaan masyarakat Desa Sitimulyo, Kecamatan Piyungan, Kabupaten Bantul dalam pembentukkan Kelompok Pengelola Sampah Mandiri. Indonesian Journal of Community Engagement. 2(02), 146-162. jurnal.ugm.ac.id 
Suhastyo, A.A (2017). Pemberdayaan masyarakat melalui pelatihan pembuatan pupuk kompos. Jurnal Pengabdian dan Pemberdayaan Masyarakat, 1(2), 63-68.

Wahyono, S. (2011). Pengolahan sampah organik dan aspek sanitasi. Jurnal Teknologi Lingkungan, 2(2), 1-7. ejurnal.bppt.go.id

Widarti, B. N., Wardhini, W. K., \& Sarwono, E. (2015). Pengaruh Rasio C/N Bahan Baku Pada Pembuatan Kompos dari Kubis dan Kulit Pisang. Jurnal Integrasi. 5(2). 75-80. jurnal.untirta.ac.id 